\title{
Photoautotrophic propagation of Brazilian ginseng [Pfaffia glomerata (Spreng.) Pedersen]
}

\author{
Lourdes Iarema • Ana Cláudia Ferreira da Cruz • Cleber Witt Saldanha • \\ Leonardo Lucas Carnevalli Dias · Roberto Fontes Vieira • \\ Evelyn Jardim de Oliveira $\cdot$ Wagner Campos Otoni
}

Received: 4 November 2011/Accepted: 3 March 2012/Published online: 22 March 2012

(C) Springer Science+Business Media B.V. 2012

\begin{abstract}
Pfaffia glomerata (Spreng.) Pedersen is a medicinal species of great interest because it produces the phytoecdysteroid 20-hydroxyecdysone (20E). Generally, because of atypical growing conditions, in vitro propagated plants function less efficiently as autotrophs and have poorly developed morphological structures. This study analyzed the autotrophic potential of $P$. glomerata propagated in vitro and evaluated the influence that this has on 20E biosynthesis. Physiological and structural parameters of plants subjected to heterotrophic, photomixotrophic and photoautotrophic growth conditions were evaluated. Levels of 20E were measured by HPLC. Plants were acclimatized in a mixture of soil, sand and substrate, in a greenhouse. Conditions that provided higher carbon input led to an increase in plant growth, and the presence of sucrose was critical, in closure systems without a gas permeable membrane, for normal anatomical development of the micropropagated plants. The absence of sucrose increased photosynthesis and conditions that enhanced photoautotrophy induced greater levels of $20 \mathrm{E}$. The increase of $20 \mathrm{E}$ levels by the photoautotrophic system offers new prospects for increasing the commercial production of this species, and for studies that could elucidate the biosynthetic pathway of phytoecdysteroids in plants.
\end{abstract}

L. Iarema - A. C. F. da Cruz - C. W. Saldanha

L. L. C. Dias - E. J. de Oliveira - W. C. Otoni $(\bowtie)$

Plant Tissue Culture Laboratory/BIOAGRO, Plant Biology

Department, Federal University of Viçosa, University Campus,

Peter Henry Rolfs Avenue, Viçosa, MG 36570-000, Brazil

e-mail: wotoni@ufv.br

R. F. Vieira

Embrapa Recursos Genéticos e Biotecnologia, Av. W5 Norte, Brasília, DF 70770-917, Brazil
Keywords $\beta$-Ecdysone - Gas exchange . Pfaffia glomerata - Photomixotrophic · Phytoecdysteroids · Secondary metabolites $\cdot$ Sucrose-free medium

\section{Introduction}

Species of Pfaffia (Amaranthaceae) are used by the medical, food and cosmetic industries (Corrêa et al. 2006), and Pfaffia glomerata, commonly known as Brazilian ginseng, has great economic value in both foreign and domestic markets as a medicinal plant (Vieira et al. 2002). Most of the wild collections of $P$. glomerata come from Brazil (Figueiredo et al. 2004); however, as with other medicinal plants (Sarasan et al. 2011), over-exploitation and unsustainable harvesting has caused a drastic decrease in natural populations and is leading to the genetic erosion of this species.

Pfaffia glomerata accumulates the phytoecdysteroid 20-hydroxyecdysone (20E), a compound that has been included in many commercial anabolic preparations for athletes (Lafont and Dinan 2003). Phytoecdysteroids are the major group isolated from Pfaffia, and 20E is the most frequently found and widely distributed phytoecdysteroid in this genus (Bakrim et al. 2008). They could have agrochemical, biotechnological, medicinal and pharmaceutical uses, and may potentially be involved in biochemical and physiological processes in plants (Festucci-Buselli et al. 2008a). It is possible that 20-hydroxyecdysone acts as a defense mechanism to protect plants against phytophagous insects (Dinan et al. 2009). Based on the fact that $P$. glomerata accumulates $20 \mathrm{E}$, this species is an interesting model that could be used to determine the precise function of $20 \mathrm{E}$ in plants and to define the genes involved in the biosynthesis of this compound. 
Currently, the goal of some studies is to develop efficient propagation techniques to increase the production of $P$. glomerata, which will ensure a regular supply of high quality homogeneous raw material that is needed to meet the increasing demand for 20E (Festucci-Buselli et al. 2008a, b; Flores et al. 2010).

In vitro propagation is a promising alternative for providing a regular supply of high quality, disease-free and homogeneous plant material within a shorter period of time (Mosaleeyanon et al., 2004). A number of studies have evaluated factors that can affect the in vitro development of P. glomerata (Nicoloso et al. 2001, 2003; Russowski and Nicoloso 2003; Skrebsky et al. 2004; Maldaner et al. 2007; Alves et al. 2010; Flores et al. 2010).

Typically, in vitro propagated plants show peculiar characteristics, such as poorly developed shoots, less epicuticular and cuticular wax, tissues with low mechanical strength, higher water content, non-functional stomata and small, thin leaves with fewer trichomes and low photoautotrophic activity (Kozai and Kubota 2001; Cha-um et al. 2011; Xiao et al. 2011). The high relative humidity and $\mathrm{CO}_{2}$ concentration inside a jar (because of reduced gas exchange) may influence anatomical, physiological and morphological plant characteristics, and can result in great losses during acclimatization (Kitaya et al. 2005).

In traditional in vitro cultivation methods, plants are supplied with exogenous carbohydrate sources to sustain growth and development because the $\mathrm{CO}_{2}$ concentration inside culture containers is reduced, which limits photosynthesis (Zobayed 2006; Kozai 2010; Xiao et al. 2011). However, photoautotrophy in vitro can be induced by excluding carbohydrates from the medium and increasing gas exchange in the culture vessel. There are other advantages to removing carbohydrates from the culture medium. For example, this prevents the rapid growth of microorganisms in the cultures, reduces costs and increases plant survival during acclimatization (Mosaleeyanon et al. 2004; Xiao and Kozai 2006; Kozai 2010; Xiao et al. 2011).

The goal of this study was to analyze the autotrophic potential of $P$. glomerata propagated in vitro by comparing physiological and structural parameters of plants subjected to heterotrophic, photomixotrophic and photoautotrophic growth conditions, and evaluated how these conditions influence the biosynthesis of $20 \mathrm{E}$.

\section{Materials and methods}

Plant material and treatments

Pfaffia glomerata shoot tips (about $9 \mathrm{~mm}$ in length) excised from 30-day-old in vitro plantlets with a pair of leaves, which were grown under heterotrophic conditions, were cultured in glass jars $(12 \mathrm{~cm}$ high $\times 5 \mathrm{~cm}$ internal diameter) containing $50 \mathrm{~mL}$ of $\mathrm{MS}$ basal medium (Murashige and Skoog 1962) supplemented with $100 \mathrm{mg} \mathrm{L}^{-1}$ myo-inositol, two levels of sucrose $\left(0\right.$ or $\left.30 \mathrm{~g} \mathrm{~L}^{-1}\right)$, and $7 \mathrm{~g} \mathrm{~L}^{-1}$ granulated agar (Merck ${ }^{\circledR}$, Darmstadt, Germany). The $\mathrm{pH}$ of medium was $5.7 \pm 0.1$ and the jars were autoclaved at $121{ }^{\circ} \mathrm{C}, 1.5 \mathrm{kgf} \mathrm{cm}^{-2}$, for $20 \mathrm{~min}$.

Four different closure systems were tested: 1 . two layers of polyvinylchloride (PVC) transparent film (Alpfilm ${ }^{\circledR}$, Curitiba, Brazil); 2. rigid polypropylene cap (RP); 3. RP with one vent hole $(10 \mathrm{~mm})$ covered with a polytetrafluoroethylene (PTFE) gas permeable membrane disk, $0.45 \mu \mathrm{m}$ pore size (MilliSeal ${ }^{\circledR}$ Air Vent, Tokyo, Japan) (RP1); and 4. RP with two vent holes $(10 \mathrm{~mm})$ covered with PTFE membrane disks (RP2). The cultures were incubated in a growth room at $25 \pm 2{ }^{\circ} \mathrm{C}, \quad 16 \mathrm{~h}$ photoperiod, $60 \mu \mathrm{mol} \mathrm{m} \mathrm{m}^{-2} \mathrm{~s}^{-1}$ irradiance from two fluorescent tubes (Sylvania HO T12, Luz do Dia, 110 W, São Paulo, Brazil).

Growth parameters

The survival percentage; plant height; leaf number and nodal segments; fresh and dry weight of aerial parts and root system; and leaf area were assessed after 30 days of in vitro culture.

Photosynthetic rate and pigments

Photosynthetic rates of in vitro $P$. glomerata plants were measured using a closed system LCA2 infrared gas analyzer (Licor Inc., Lincoln, Nebraska, EUA). The reference air $\left(500 \mu \mathrm{mol} \mathrm{mol}{ }^{-1} \mathrm{CO}_{2}\right)$ was pumped into culture jars at a constant flow rate $\left(0.5 \mathrm{~L} \mathrm{~min}^{-1}\right)$. Plants were exposed to $500 \mu \mathrm{mol} \mathrm{m} \mathrm{m}^{-2} \mathrm{~s}^{-1}$ irradiance prior to and during the analysis. Determination of carotenoids and chlorophyll $a$ and $b$ followed Wellburn (1994). Six leaf disks (5 mm diameter) were taken from the third fully expanded leaf from the shoot tip and incubated in a $5 \mathrm{~mL}$ dimethyl sulfoxide solution (saturated with $\mathrm{CaCO}_{3}$ ) at room temperature, for $48 \mathrm{~h}$. Absorbances at 665, 645 and $480 \mathrm{~nm}$ were determined using a spectrophotometer (Hitachi U-2000, Tokyo, Japan).

Estimation of the number of gas exchanges per hour

The amount of gas exchange provided by each seal type, except for PVC, was determined as described by Fujiwara and Kozai (1995). Therefore, the headspace of each flask containing a different membrane type was saturated with a mixture of carbon dioxide $\left(\mathrm{CO}_{2}\right)$ at a concentration of $2.5 \%$. The readings of the inner $\mathrm{CO}_{2}$ concentrations were performed with a Headspace Gas Analyzer 6600 (IIlinois $($ ) Instruments, Johnsburg, IL, USA). The amount of gas 
exchange per hour ( $N^{\prime}$ ) for each type of seal was estimated by the following equation: $N^{\prime}=\frac{1}{T} \ln \frac{\mathrm{C}_{1}-\mathrm{C}_{\text {out }}}{\mathrm{C}_{2}-\mathrm{C}_{\text {out }}}$ (Fujiwara and Kozai 1995). Where $T$ represents the time (in hours) between two readings ( 1 and 2); $\mathrm{C}_{1}$ and $\mathrm{C}_{2}$ correspond to the inner $\mathrm{CO}_{2}$ concentrations in the flasks at times 1 and 2; $\mathrm{C}_{\text {out }}$ is the $\mathrm{CO}_{2}$ concentration in the environment external to the flask.

Anatomy and histochemical characterization

For the anatomical studies, samples from the middle region of fully expanded leaves were fixed in FAA (formalin: acetic acid: $50 \%$ ethyl alcohol) for 24 h (Johansen 1940), washed in 70 alcohol, dehydrated through a graded series of ethyl alcohol and embedded in methacrylate (Historesin, Leica $\left.^{\circledR}\right)$. Cross and longitudinal sections ( $8 \mu \mathrm{m}$ thick) were cut using a rotary automatic microtome (RM 2155-Leica), with disposable stainless steel blades, and stained with toluidine blue (O'Brien and McCully 1981) for $10 \mathrm{~min}$, at $\mathrm{pH}$ 4.0. The sections were then mounted on glass slides with the synthetic resin Permount ${ }^{\circledR}$.

For the hystochemical analyses, sections of the middle third section of the stems were cut with a hand microtome (LPC, Rolemberg \& Bhering, Belo Horizonte, Brazil) and stained with phloroglucin acid to detect lignin (Johansen 1940) and ruthenium red (Johansen 1940) and coriphosphine to detect pectins (Ueda and Yoshioka 1976). Sections stained with neutral red were examined under UV light using a blue excitation filter (BP 450-490 nm). Observations and photography were carried out with an Olympus SZH stereo microscope (Olympus Optical, Tokyo, Japan) and an Olympus AX70TRF microscope (Olympus Optical, Tokyo, Japan) with a U-Photo Camera System (Spot Insight Color 3.2.0, Diagnostic Instruments Inc., USA).

Ultrastructural analysis: scanning electron microscopy (SEM)

Samples of the middle region of leaf blades (about $5 \mathrm{~mm}$ in width) were taken from leaves on the second node, fixed in Karnovsky solution (2.5\% glutaraldehyde and $2.5 \%$ paraformaldehyde in $0.05 \mathrm{M}$ cacodilate buffer, $\mathrm{pH}$ 7.2) and postfixed with $1 \%$ osmium tetroxide. After dehydration through a graded series of ethyl alcohol, followed by critical point drying in a Bal-Tec CPD 030 (Bal-Tec, Balzers, Liechenstein), the samples were mounted on stubs and coated with gold using a FDU010 sputter coater (Bal-Tec, Balzers, Liechtenstein). Examinations and photography were carried out using a Leo 1430VP scanning electron microscope (Zeiss, Cambridge, England). All images were processed digitally.
HPLC determination of 20-hydroxyecdysone (20E)

Methanolic extracts from 3 independent samples were prepared with $100 \mathrm{mg}$ of powdered plant material in $10 \mathrm{~mL}$ of methanol, and incubated at $25^{\circ} \mathrm{C}$ under agitation for 7 days. Quantification of 20E in the methanolic extract was performed using High Performance Liquid Chromatography (HPLC) according to Festucci-Buselli et al. (2008b). The calibration curve was obtained by adding the standard 20-hydroxyecdysone (Sigma-Aldrich) to methanol at 20, 40, 60, 80, 100, 125, 150, and $200 \mathrm{mg} \mathrm{L}^{-1}$. The data from this analysis are presented as percentages ( $\mathrm{mg}$ for $100 \mathrm{mg}$ of powdered plant dry matter).

Plant acclimatization

After 30 days in culture, the in vitro plantlets were transferred to $300 \mathrm{~mL}$ plastic cups containing a 2:2:1 mixture of soil, sand and the substrate Plantmax ${ }^{\circledR}$ (DDL Agroindústria, Betel Paulínia, Brazil), wrapped in $12 \times 25 \mathrm{~cm}$ plastic bags for 15 days and then transferred to a greenhouse.

Experimental design and statistical analysis

The experiment was arranged in a $4^{2}$ factorial, completely randomized design, with four types of seals (PVC, RP, RP1, and RP2) and two sucrose concentrations (0 and $30 \mathrm{~g} \mathrm{~L}^{-1}$ ), with six replicates, each represented by 5 jars containing 5 plants each. All variables were examined by analysis of variance and means were compared with Tukey's test at $5 \%$ of probability.

Data about dry root mass were analyzed using square root transformation. All statistical analyses were performed at a $5 \%$ probability level, using the software GENES (Cruz 2006). The experiment was repeated twice.

\section{Results and discussion}

Conditions providing higher carbon input led to increased plant growth

In vitro plants grown in the presence or absence of sucrose and under different types of jar seals showed remarkable morphological differences (Fig. 1, Table 1). Treatments devoid of both sucrose and the venting PTFE membrane (Fig. 1f) had the lowest growth parameters, and this compromised plant development and led to mortality rates that were as high as $80 \%$. Likewise, lower leaf area indices were obtained in medium lacking sucrose in combination with the PVC film or RP seals without vent holes (Table 1). The highest leaf area indices were achieved in cultures 

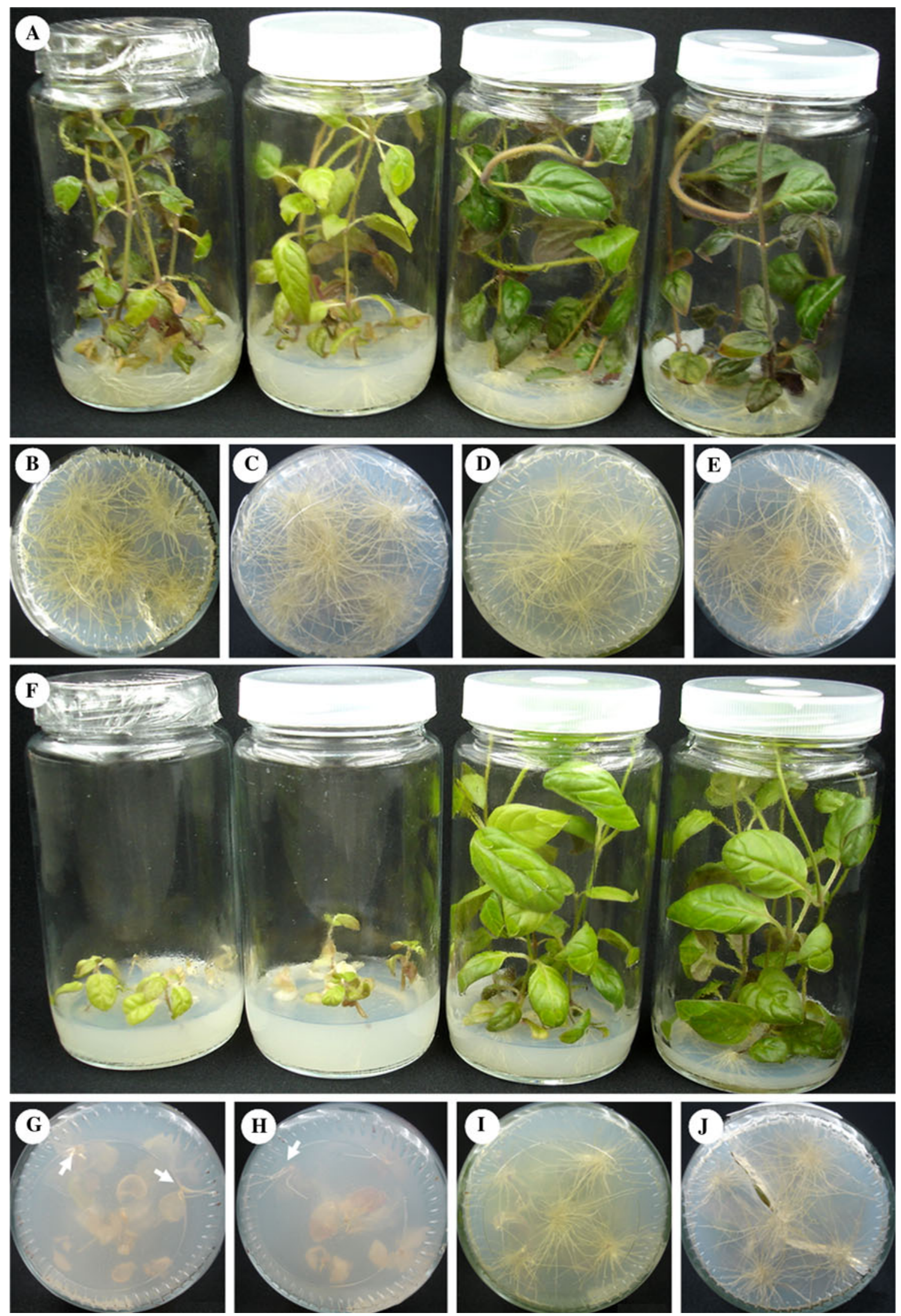
4Fig. 1 Pfaffia glomerata plantlets propagated in vitro under different closure systems, at 32 days of culture: PVC transparent film; rigid polypropylene $(R P)$ cap; RP cap with one gas permeable membrane disk (RP1); and RP cap with two gas permeable membrane disks (RP2) (from left to right, respectively), on medium supplemented with $30 \mathrm{~g} \mathrm{~L}^{-1}$ sucrose (a); roots of $P$. glomerata plantlets grown on sucrose-supplemented medium (b-e); plantlets grown on sucrose-free medium (f); roots of $P$. glomerata plantlets grown on sucrose-free medium $(\mathbf{g}-\mathbf{j})$. Arrows $(\mathbf{g}, \mathbf{h})$ indicate the development of a few roots

grown in jars closed with the PTFE membrane (RP1 and RP2), regardless of the presence of sucrose.

The amount of gas exchange per hour, estimated by the use of $\mathrm{CO}_{2}$ in flasks sealed with RP, RP1 and RP2), was 0.03 (RP), 0.37 (RP1), and 0.86 (RP2). In the absence of sucrose and a porous membrane, the gas exchange was not enough to support plant growth (Fig. 1f; Table 1). The use of gas permeable membranes allowed for increased natural ventilation in the culture vessels, providing an adequate $\mathrm{CO}_{2}$ concentration, which increased photosynthesis and the growth rate (Kitaya et al. 2005). In this study, biomass accumulation in shoots of $P$. glomerata was a function of the presence of the PTFE membranes in the caps of culture jars on both sucrose-supplemented and non-supplemented media. Nevertheless, growth responses as a function of gas exchange in the culture environment depend on the species, and the effect of gas exchange varies with the presence or absence of sucrose in the medium (Shim et al. 2003). Kozai and Kubota (2001) found that the growth of explants from most woody species was greater under photoautotrophic conditions when compared to photomixotrophic conditions.

The presence of sugar in the culture medium alters plant biochemistry, physiology and morphology of vitroplants (Badr et al. 2011). When plants are grown in vitro on medium devoid of sucrose, there is the need to increase irradiance, $\mathrm{CO}_{2}$ diffusion and humidity (Kozai and Kubota 2001) to enhance photosynthesis, transpiration, and dry mass accumulation (Aitken-Christie et al. 1995; Kitaya et al. 2005).

Greater development of the root system was observed in sucrose-supplemented medium (Fig. 1a-e). Structural and physiological analyses corroborated the variations observed. The absence of sucrose in the medium of jars sealed with the RP and PTFE membranes reduced fresh and dry root mass (Table 1). Root growth was reduced in the treatments without sucrose, which was possibly a result of the metabolic sink created by the investment in the photosynthetic apparatus (because photosynthesis became the only route for carbon uptake).

In general, the highest mean values for almost all of the tested variables were observed in the presence of sucrose, without any differences from the influence of the closure type (Table 1). The addition of the carbon source stimulated biomass production in $P$. glomerata. An increase in dry matter of in vitro propagated $P$. glomerata with increasing sucrose concentrations has been reported by other authors (Nicoloso et al. 2003; Skrebsky et al. 2004; Maldaner et al. 2006, 2007).

Absence of sucrose increased photosynthesis

Gas exchange was increased in the sucrose-free media, and plants grown without the carbohydrate had the highest photosynthetic rates (Table 2). Considering the effect of the closure type with the addition of sucrose, we found that only chlorophyll $a$ and total chlorophyll differed
Table 1 Growth analysis of Pfaffia glomerata propagated in vitro under different closure systems and sucrose concentrations

Means followed by the same capital letter in the row and small letter in the column, for each variable, are not significantly different by the Tukey test at $5 \%$ of probability

\begin{tabular}{llrrrr}
\hline Variables & $\begin{array}{l}\text { Sucrose } \\
\left(\mathrm{g} \mathrm{L}^{-1}\right)\end{array}$ & Treatments & & & \\
\cline { 4 - 6 } & & $\mathrm{PVC}$ & $\mathrm{RP}$ & $\mathrm{RP} 1$ & $\mathrm{RP} 2$ \\
\hline Leaf area $\left(\mathrm{cm}^{2}\right)$ & 0 & $0.77 \mathrm{Bb}$ & $0.97 \mathrm{Bb}$ & $3.03 \mathrm{Aa}$ & $3.21 \mathrm{Aa}$ \\
& 30 & $1.51 \mathrm{Aa}$ & $1.49 \mathrm{Aa}$ & $2.04 \mathrm{Ab}$ & $2.29 \mathrm{Ab}$ \\
Height $(\mathrm{cm})$ & 0 & $3.30 \mathrm{Bb}$ & $3.78 \mathrm{Bb}$ & $13.29 \mathrm{Aa}$ & $14.21 \mathrm{Aa}$ \\
& 30 & $14.10 \mathrm{Aa}$ & $15.24 \mathrm{Aa}$ & $13.47 \mathrm{Aa}$ & $11.12 \mathrm{Ab}$ \\
Leaf number & 0 & $1.73 \mathrm{Bb}$ & $2.25 \mathrm{Bb}$ & $10.73 \mathrm{Aa}$ & $11.87 \mathrm{Aa}$ \\
& 30 & $13.87 \mathrm{Aa}$ & $14.47 \mathrm{Aa}$ & $12.40 \mathrm{Aa}$ & $9.80 \mathrm{Aa}$ \\
Number of nodal segments & 0 & $2.17 \mathrm{Ab}$ & $2.83 \mathrm{Ab}$ & $4.73 \mathrm{Aa}$ & $4.77 \mathrm{Aa}$ \\
& 30 & $6.90 \mathrm{Aa}$ & $6.80 \mathrm{Aa}$ & $5.27 \mathrm{Aa}$ & $4.57 \mathrm{Aa}$ \\
Fresh mass of aerial parts $(\mathrm{g})$ & 0 & $0.160 \mathrm{Bb}$ & $0.205 \mathrm{Bb}$ & $2.364 \mathrm{Aa}$ & $2.868 \mathrm{Aa}$ \\
& 30 & $2.291 \mathrm{Aa}$ & $2.846 \mathrm{Aa}$ & $2.756 \mathrm{Aa}$ & $2.432 \mathrm{Aa}$ \\
Fresh mass of roots $(\mathrm{g})$ & 0 & $0.053 \mathrm{Bb}$ & $0.095 \mathrm{Bb}$ & $0.314 \mathrm{Ab}$ & $0.319 \mathrm{Ab}$ \\
& 30 & $1.027 \mathrm{Aa}$ & $1.122 \mathrm{Aa}$ & $1.280 \mathrm{Aa}$ & $1.586 \mathrm{Aa}$ \\
Dry mass of aerial parts $(\mathrm{g})$ & 0 & $0.004 \mathrm{Bb}$ & $0.005 \mathrm{Bb}$ & $0.045 \mathrm{Ab}$ & $0.058 \mathrm{Ab}$ \\
& 30 & $0.062 \mathrm{Aa}$ & $0.068 \mathrm{Aa}$ & $0.091 \mathrm{Aa}$ & $0.126 \mathrm{Aa}$ \\
Dry mass of roots $(\mathrm{g})$ & 0 & $0.006 \mathrm{Bb}$ & $0.014 \mathrm{Bb}$ & $0.049 \mathrm{Ab}$ & $0.051 \mathrm{Ab}$ \\
& 30 & $0.175 \mathrm{Aa}$ & $0.167 \mathrm{Aa}$ & $0.200 \mathrm{Aa}$ & $0.194 \mathrm{Aa}$ \\
\hline
\end{tabular}


Table 2 Physiological parameters related to photosynthesis of Pfaffia glomerata propagated in vitro under different closure systems and sucrose concentrations

\begin{tabular}{|c|c|c|c|c|c|}
\hline \multirow[t]{2}{*}{ Variables } & \multirow[t]{2}{*}{ Sucrose $\left(\mathrm{g} \mathrm{L}^{-1}\right)$} & \multicolumn{4}{|c|}{ Treatments } \\
\hline & & PVC & $\mathrm{RP}$ & RP1 & $\mathrm{RP} 2$ \\
\hline \multirow[t]{2}{*}{ Photosynthesis $\left(\mu \mathrm{mol} \mathrm{CO} \mathrm{Cg}^{-1} \mathrm{~s}^{-1}\right.$ ) } & 0 & $-{ }^{\mathrm{a}}$ & $-{ }^{\mathrm{a}}$ & $65.39 \mathrm{Aa}^{\mathrm{b}}$ & $60.94 \mathrm{Aa}$ \\
\hline & 30 & $32.25 \mathrm{Ab}$ & $20.14 \mathrm{Ab}$ & $30.17 \mathrm{Ab}$ & $24.14 \mathrm{Ab}$ \\
\hline \multirow[t]{2}{*}{ Chlorophyll $a\left(\mu \mathrm{g} \mathrm{cm}^{-2}\right)$} & 0 & 7.11Bb & $6.13 \mathrm{Bb}$ & $15.80 \mathrm{Ab}$ & $20.47 \mathrm{Ab}$ \\
\hline & 30 & $20.26 \mathrm{Ba}$ & $18.99 \mathrm{Ba}$ & $38.01 \mathrm{Aa}$ & 44.51Aa \\
\hline \multirow[t]{2}{*}{ Chlorophyll $b\left(\mu \mathrm{g} \mathrm{cm}^{-2}\right)$} & 0 & $2.50 \mathrm{Ab}$ & $2.30 \mathrm{Ab}$ & $4.78 \mathrm{Ab}$ & $6.50 \mathrm{Ab}$ \\
\hline & 30 & $6.48 \mathrm{Aa}$ & $5.86 \mathrm{Aa}$ & $12.39 \mathrm{Aa}$ & $14.65 \mathrm{Aa}$ \\
\hline \multirow[t]{2}{*}{ Chlorophyll total $\left(\mu \mathrm{g} \mathrm{cm}^{-2}\right)$} & 0 & $9.61 \mathrm{Bb}$ & $8.43 \mathrm{Bb}$ & $20.58 \mathrm{Ab}$ & $26.97 \mathrm{Ab}$ \\
\hline & 30 & $26.74 \mathrm{Ba}$ & $24.86 \mathrm{Ba}$ & $50.40 \mathrm{Aa}$ & $59.16 \mathrm{Aa}$ \\
\hline \multirow[t]{2}{*}{ Carotenoids $\left(\mu \mathrm{g} \mathrm{cm}^{-2}\right)$} & 0 & $1.76 \mathrm{Ab}$ & $1.49 \mathrm{Ab}$ & $3.01 \mathrm{Ab}$ & $3.89 \mathrm{Ab}$ \\
\hline & 30 & $3.87 \mathrm{Aa}$ & $3.65 \mathrm{Aa}$ & 6.69Aa & 7.78Aa \\
\hline
\end{tabular}

${ }^{a}$ Plants grown under these conditions did not grow, hence it was not possible to perform the analysis

a Means followed by same capital letter in the row and small letter in the column, for each variable, are not significantly different by the Tukey test at $5 \%$ of probability

significantly (Table 2). The treatments without a gas permeable membrane, regardless of sucrose concentration, showed the lowest means for pigment content. But, the contents of chlorophyll $a$, chlorophyll $b$, total chlorophyll and carotenoids had the highest means when the medium contained sucrose (Table 2).

The $\mathrm{CO}_{2}$ content in headspace and light intensity are the factors that limit photosynthesis in in vitro conditions (Galzy and Compan 1992).

The influence of the closure system, and the sucrose concentration, on the photosynthetic rate of P. glomerata reflected the heterotrophic condition in which the plants cultivated in vitro, using a traditional method (PVC and $\mathrm{RP}$ ), was maintained. The higher rate of photosynthesis in $P$. glomerata grown in the absence of sucrose, compared with plants grown in the presence of sucrose with the same closure type, was also reported in grapevine; however, this occurred when the plants were subjected to higher gas exchange rates (2.5 and $4.4 \mathrm{~h}^{-1}$ ) (Shim et al. 2003). When present in the culture medium, sucrose is preferentially absorbed by the plant as a carbohydrate source, inhibiting photosynthetic activity even when ventilation increases (Kozai and Sekimoto 1988). Plants grown without sucrose had a higher photosynthetic rate because this was the only route to carbon fixation.

No leaf senescence was observed in plants grown with the PTFE membranes, unlike treatments without both sucrose and a membrane. Chlorophyll loss is a phenomenon typically associated with senescence (Lu et al. 2003). The concentrations of total chlorophyll in sucrose-free medium combined with a membrane were similar to those in sucrose-added medium without a membrane. High concentrations of sucrose in the medium can inhibit chlorophyll accumulation in vitro (Neumann and Bender 1987). Conversely, in P. glomerata, plants grown in treatments with both sucrose and a membrane had increased synthesis of photosynthetic pigments (chlorophyll $a, b$ and carotenoids), corroborating the results obtained for Vitis vinifera and Scrophularia yoshimurae (Gribaudo et al. 2003; Tsay et al. 2006), in which gaspermeable culture conditions favoured the increase of chlorophyll content. However, for in vitro cultivation, there does seem to be a pattern of responses for the content of photosynthetic pigments as a function of sucrose concentration in the culture medium.

Sucrose is critical for normal development of $P$. glomerata plants micropropagated in closure systems without a gas permeable membrane

In vitro plants, in general, are poorly developed, with less epicuticular waxes, reduced supportive tissues, higher water content, non-functional stomata, thin leaves, few trichomes and low photoautotrophic activity (Kozai 1991; Kozai and Kubota 2001). These characteristics were not observed in $P$. glomerata grown using the traditional method of tissue culture, even in the treatments without sucrose; however, there were better results in the RP2 treatments (Fig. 2). Plants from all treatments without sucrose had a poorly developed vascular system and supportive tissues (Fig. 2d-f), showing a typical organization of cells and tissues found in plants grown heterotrophically. There was a visible reduction in the size of vascular bundles of the midrib in treatments without sucrose compared with treatments using the same closure systems and sucrose (Fig. 2f, 1). Also, plants grown without both sucrose and a 
Fig. 2 Cross sections of the middle portion of the leaf of Pfaffia glomerata propagated in vitro under different closure systems and sucrose concentrations. a-f Rigid polypropylene $(R P)$ cap without membrane with $(\mathbf{a}-\mathbf{c})$ and without (d-f) sucrose; $\mathbf{g}-\mathbf{l}$ RP cap with two membrane disks with $(\mathbf{g}-\mathbf{i})$ and without $(\mathbf{j}-$ l) sucrose. $\mathbf{a}, \mathbf{d}, \mathbf{g}, \mathbf{j}$ Detail of leaf margin; $\mathbf{b}, \mathbf{e}, \mathbf{h}, \mathbf{k}$ detail of leaf blade; $\mathbf{c}, \mathbf{f}, \mathbf{i}, \mathbf{l}$ detail of midrib. $A b$ abaxial surface of the epidermis; $A d$ adaxial surface of the epidermis; $S t$ stomata; $V b$ vascular bundle; $I d$ idioblast; $P p$ palisade parenchyma; $S p$ spongy parenchyma; $S u$ supportive tissue; + (presence) and - (absence) of sucrose. Arrowhead indicates the presence of an idioblast containing a druse. Bars $50 \mu \mathrm{m}$

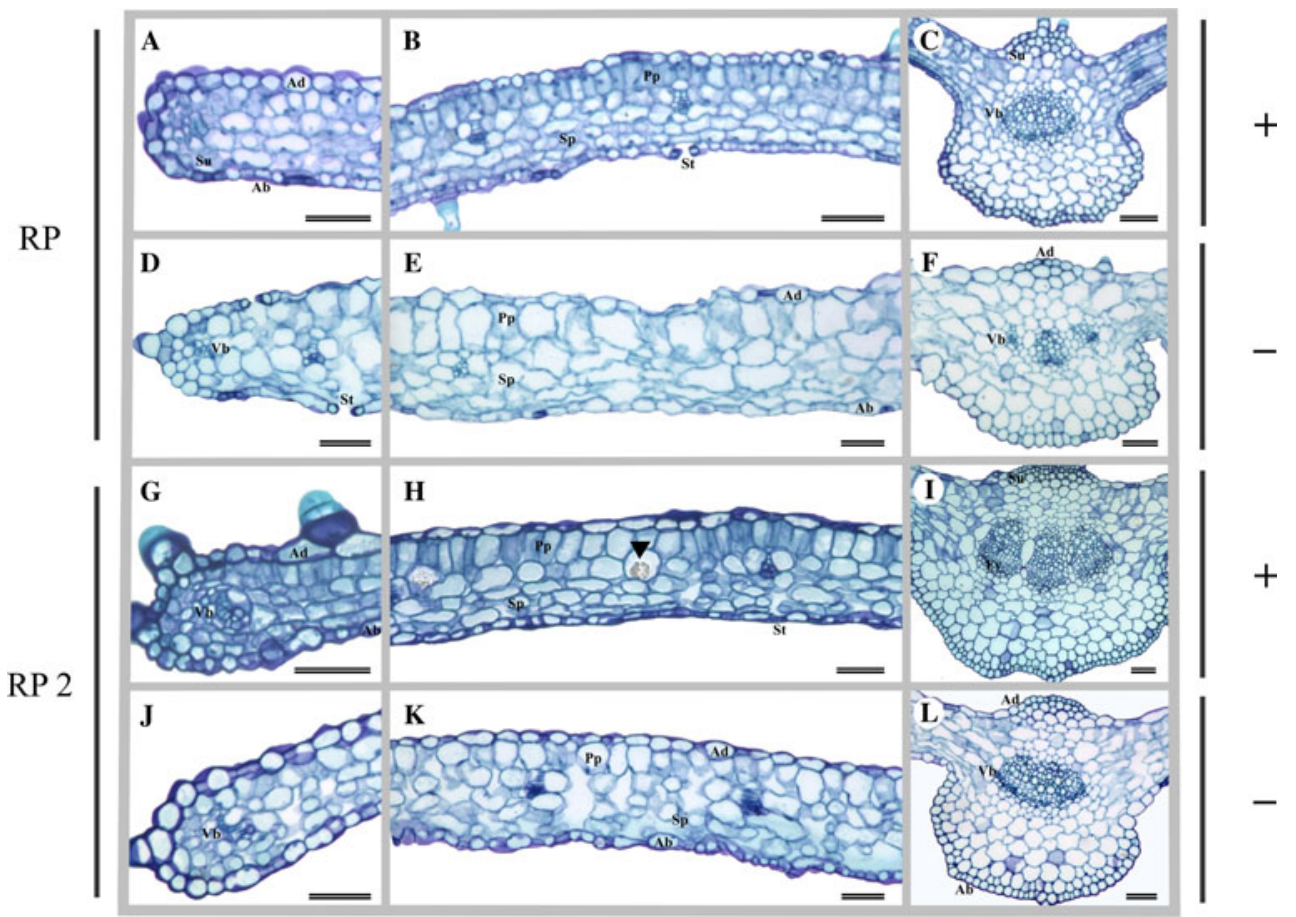

PTFE membrane lacked supportive tissue (collenchyma) in the subepidermal region of the midrib of the leaf (Fig. 2f). However, collenchyma formed in treatments with a membrane, and was more developed in treatments that used the RP2 membrane (Fig. 21).

The percent reduction in dry weight of $P$. glomerata grown photoautotrophically, compared with the other treatments, was reflected in the leaf anatomy, because the leaf is the most susceptible organ to acclimatization. On the other hand, stem anatomical characteristics showed significant differences, which were mainly related to cell wall lignification and the size of vessel elements. Water accumulation in the plant results in weak organs and tissues with reduced mechanical support and thin cell walls (Donnelly and Tisdall 1993; Jausoro et al. 2010). This accumulation may be caused by the nutritional composition of the medium or the cultivation environment, inhibiting cell wall deposition and the formation of collenchyma and sclerenchyma (Donnelly et al. 1985) and restricting the development of the vascular system (Donnelly and Tisdall 1993). Such characteristics were observed in P. glomerata in treatments with lower biomass production, and without a membrane and sucrose.

The leaf of $P$. glomerata is amphistomatic, with a distinct dorsiventral structure in normally developed plants
(Fig. 2). In the treatment with sucrose-free medium and RP2, the development of plants grown in vitro was typical, with large intercellular spaces and more globular palisade parenchyma (Fig. 2k), compared to plants grown on sucrose-supplemented medium with the same closure system (Fig. 2h). In treatments without both sucrose and a membrane, cells of the palisade parenchyma were larger and accounted for nearly half of the mesophyll volume (Fig. 2e).

Scanning electron microscopy showed that in plants grown with sucrose, regardless of the closure system used, or sucrose-free medium using RP2, the epidermal cells had sinuous walls (Fig. 3a, d, g, j) with epidermal appendages, such as non-glandular trichomes (Fig. 3h, j), which together with stomata (Fig. 3c, h, i) were more frequent on the abaxial surface. Stomata had a typical elliptic shape and were slightly raised above the other epidermal cells (Fig. 3). Non-glandular trichomes were uniseriate and multicellular with elongate cells, and had a surface ornamented with small warts, including the region of cell union/contact, which was typically dentate (Fig. 3f, g, l).

The high relative humidity, typical of the traditional method of tissue culture, reduces deposition of epicuticular waxes and alters the cuticle structure, mesophyll cells and the ability for leaf stomata to function. In this study, leaves 


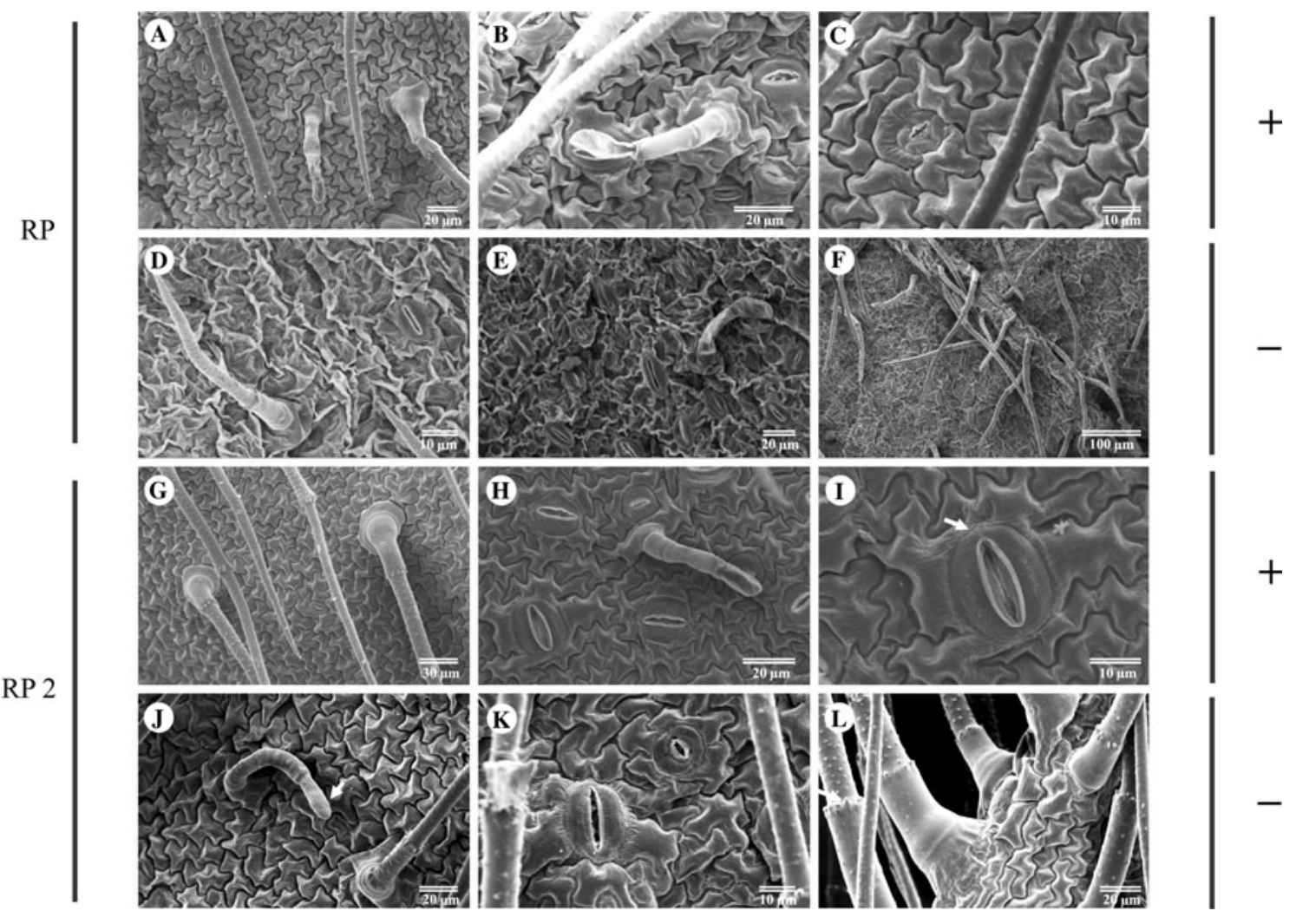

Fig. 3 Leaf surface scanning electron micrographs of Pfaffia glomerata propagated in vitro under different closure systems and sucrose concentrations. a-f Rigid polypropylene $(R P)$ cap without membrane with $(\mathbf{a}-\mathbf{c})$ and without $(\mathbf{d}-\mathbf{f})$ sucrose; $\mathbf{g}-\mathbf{l}$ RP cap with two membrane disks with $(\mathbf{g}-\mathbf{i})$ and without (j-l) sucrose. $\mathbf{a}, \mathbf{d}, \mathbf{g}, \mathbf{j}$ Details the adaxial

of plants grown in medium containing sucrose, regardless of the closure type, and in sucrose-free medium combined with caps with one or two membranes, showed normal structural development (Fig. 3a-c, g-i). Development of plants in sucrose-free medium without the PTFE membrane was affected (Fig. 3d-f). Epidermal cells with undefined walls prevented delimitation of cell boundaries; stomatal development was abnormal, most had bulged pores; trichomes were clearly reduced in number, and were broken or malformed (Fig. 3e, f).

Morphology of stomata and epidermal cells was more significantly different in plants grown with RP2 when compared with the other treatments, and it was possible to see the initial formation of striations in subsidiary cells, as well as at different developmental stages (Fig. 3g-1). Stomata that form under conventional conditions of tissue culture are often malformed and unable to function (Desjardins et al. 1987; Santamaria and Kerstiens 1994; Pospísilová et al. 1999), making the plants susceptible to large transpiration losses, because they play a key role in the regulation of gas exchange and transpiration and are also involved with photosynthetic capacity and plantlet acclimatization. These characteristics were not observed in leaf surface; $\mathbf{b}, \mathbf{e}, \mathbf{h}, \mathbf{k}$ details of the abaxial surface; $\mathbf{f}$ detail of malformed stomata showing bulged pores; $\mathbf{c}, \mathbf{i}, \mathbf{k}$ detail of normally developed stomata-arrow indicates initial formation of striations; f detail of a secondary vein, on the abaxial surface; $Y$ detail of ornate trichomes on leaf margins

P. glomerata from treatments that used sucrose or PTFE membranes, which provided better gas exchange.

Histochemical analyses confirmed the impairment of the structural development of plants grown in jars without sucrose and PTFE membranes (Fig. 4d-f), whereas in the other treatments plants showed normal development (Fig. 4a-c, g-l). The middle third stem section of $P$. glomerata plantlets grown in vitro showed a uniseriate epidermis with stomata and non-glandular trichomes. The subepidermal layers of the cortex (2-4) differentiated in angular collenchyma in treatments with sucrose (Fig. 4a, b, $\mathrm{g}, \mathrm{h})$ and sucrose-free medium with membrane disks (Fig. 4j, k), whereas plants grown without sucrose and a membrane did not develop supportive tissues in the cortical region (Fig. 4d, e). The collenchyma did not form a continuous layer/ring, and was interrupted in regions of the epidermis with stomata and/or trichomes by chlorenchyma, which formed the remaining cortical cell layers.

Pectins were detected in the cortical region using the coriphosphine reagent and fluorescence microscopy, which resulted in bright orange-red staining of collenchyma cells and weak staining of pith cells (Fig. 4a, d, g, j). The qualitative analysis showed that chlorenchyma cells were 


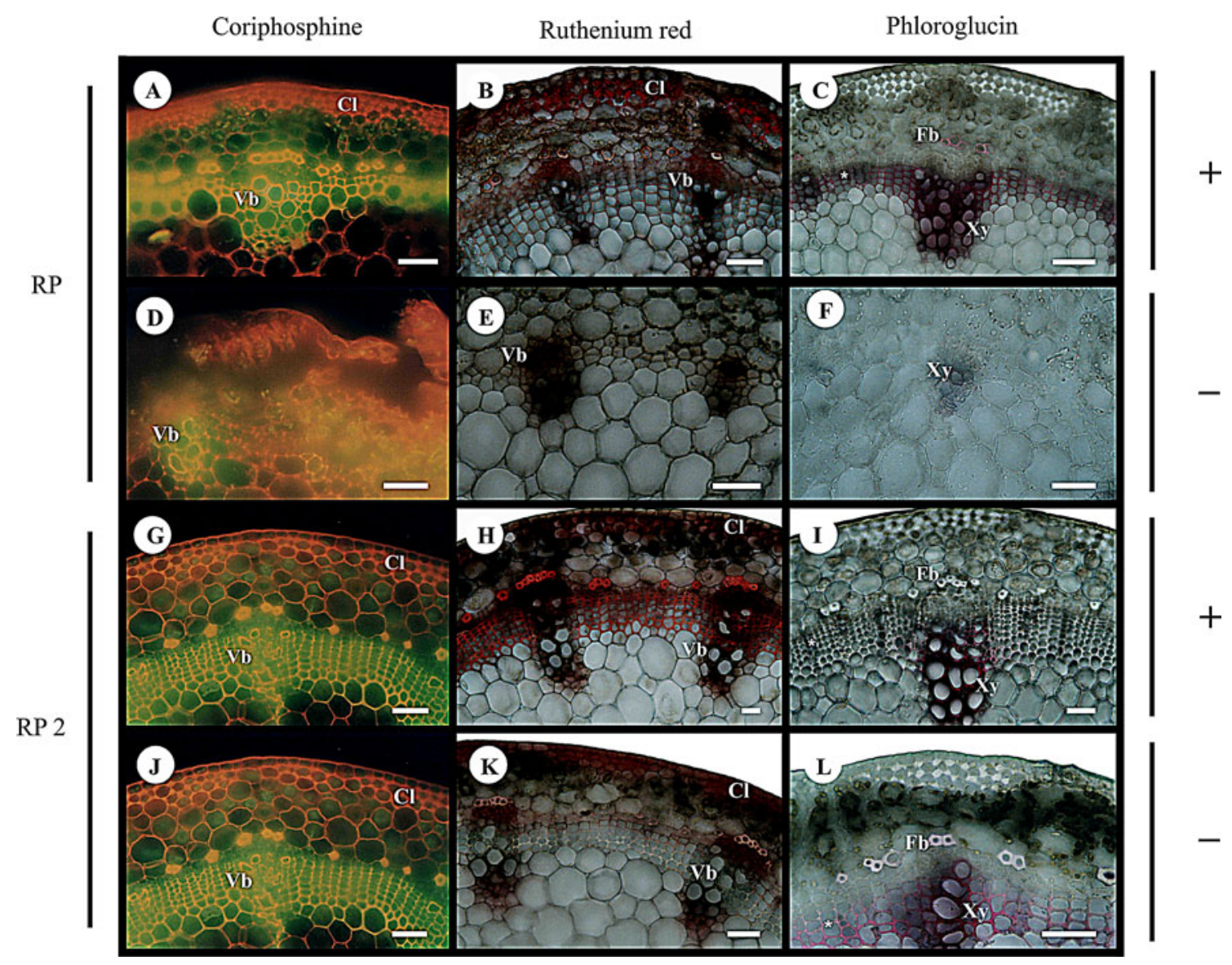

Fig. 4 Cross sections of the middle portion of the stem of Pfaffia glomerata propagated in vitro under different closure systems and sucrose concentrations, and stained with the following reagents: coriphosphine induced-fluorescence $(\mathbf{a}, \mathbf{d}, \mathbf{g}, \mathbf{j})$; ruthenium red (b, e,

smaller and cell walls were thinner in the treatment supplemented with sucrose and without a membrane, when compared with plants grown in jars with two membrane disks, regardless of the addition of sucrose to the culture medium (Fig. 4).

Staining with phloroglucinol detected lignified structures in stem sections from the treatments with sucrosesupplemented medium (Fig. 4c, i). As observed for other reagents, plants grown in the RP treatment showed no cell wall thickening and incipient lignification of the vascular tissue (Fig. 4f). Interestingly, stem sections from plants grown in medium that lacked sucrose and flasks with membranes displayed an increased degree of lignification (Fig. 41). An intense staining of vascular bundles in the remaining treatments indicated strong xylem lignification and cell wall thickening in the interfascicular region, forming a continuous ring (Fig. 2f). The reaction with phloroglucinol also revealed the presence of fibers attached to the bundles in the interfascicular region, which tended to be arranged in a circle. The largest number (5-9) of cell layers with cell wall thickening in the interfascicular region h, k); and phloroglucin (c, f, i, l). a-c Rigid polypropylene $(R P)$ cap; d-f RP with two membrane disks (RP2). $\mathrm{Cl}$ collenchyma; $\mathrm{Fb}$ fiber; $\mathrm{Vb}$ vascular bundle, and $X y$ xylem; + (presence) and - (absence) of sucrose. Bars $50 \mu \mathrm{m}$

was found in treatments that used membranes and media with or without sucrose (Fig. $4 \mathrm{~g}-\mathrm{i}, \mathrm{j}-\mathrm{l}$ ). However, the plants grown with sucrose and two membrane disks (Fig. 4g-i) probably had a more intense lignification, because no reaction with phloroglucinol was observed in the interfascicular region or in the fibers. On the other hand, we observed fewer (3-5) cell layers with cell wall thickening, in the interfascicular region, in the treatments with sucrose-supplemented medium without a membrane (Fig. 4c) and treatments with sucrose-free medium using a membrane disks (Figs. 2f, 1; 41).

Conditions that enhance photoautotrophy induced greater levels of $20 \mathrm{E}$

The development of a system to allow the commercial production of plant secondary metabolites in vitro has been proposed by various authors (Zhao et al. 2005; Chen et al. 2006; Lee et al. 2010; Zare et al. 2010; Savio et al. 2012).

Plants grown in the absence of sucrose and without a membrane did not developed under the experimental 
Table 3 Production of $20 \mathrm{E}$ in the aerial parts of Pfaffia glomerata grown in vitro under different closure systems and sucrose concentrations after 30 days of culture

\begin{tabular}{llllll}
\hline Variable & $\begin{array}{l}\text { Sucrose } \\
\left(\mathrm{g} \mathrm{L}^{-1}\right)\end{array}$ & \multicolumn{4}{l}{ Treatments } \\
\cline { 3 - 6 } & & PVC & RP & RP1 & RP2 \\
\hline$\beta$-ecdisone & 0 & $-^{\mathrm{a}}$ & ${ }^{\mathrm{a}}$ & $0.035 \mathrm{Aa}$ & $0.031 \mathrm{Aa}$ \\
level $(20 \mathrm{E} \%)$ & 30 & $0.017 \mathrm{~A}$ & $0.018 \mathrm{~A}$ & $0.019 \mathrm{Ab}$ & $0.017 \mathrm{Ab}$ \\
\hline
\end{tabular}

Means followed by same capital letter in the row and small letter in the column are not significantly different by the Tukey test at $5 \%$ of probability

${ }^{\text {a }}$ Plants grown under these conditions did not grow, hence it was not possible to perform the chemical analysis

conditions, and the dry matter produced was not enough to quantify. Also, 20E was not detected in the roots in any treatment. Thus, the comparative analyses described here excluded the treatments with sucrose-free medium without a membrane, as well as the root system.

When analyzing the factors in an isolated manner, considering the different closure systems and levels of sucrose, we found that in the absence of sucrose there was no statistical difference between the treatments using one or two membrane disks (Table 3 ). There was also no statistical difference among the treatments supplemented with $30 \mathrm{~g} \mathrm{~L}^{-1}$ sucrose (Table 3). However, when examining the different levels of sucrose within each type of closure, we found that sucrose-free medium associated with PTFE membranes had the highest levels of the active principle (20E), which was a significant accumulation (Table 3 ). These results differ from those described by Hao and Guan (2012), where the addition of sugars increased the accumulation of secondary metabolites. However, these authors worked with adventitious roots whereas we worked with the whole plant.

Dry matter production was higher in the presence of sucrose, but the percentage of the active principle of interest (20E) was greater in plants grown photoautotrophically.

The chemical nature and concentration of phytoecdysteroids in plants may vary according to the plant part, developmental stage and environmental conditions (Dinan 2001). In cultivation in vitro, plants do not form root tubers because of the reduced cultivation time (about 30 days), which is determined by the depletion of the medium and rapid plant growth. Subcultures are therefore required, but interfere directly with the presence of $20 \mathrm{E}$, because its accumulation in the roots, as well as formation of root tubers, occurs gradually (Festucci-Buselli et al. 2008b).

Whether secondary metabolites are produced mainly in the roots and transported to leaves, or biosynthesized in the leaves and selectively transported from leaves to roots and whole plant, remains an unresolved question that needs to be further investigated. Therefore, it is noteworthy that production of the active principle in the aerial part of $P$. glomerata grown in vitro was directly influenced by the photoautotrophic condition.

The increment level of $20 \mathrm{E}$ may be related to the adaptation to a new condition, such as when plants use secondary metabolites to rapidly and dynamically respond to an environmental stress (Metlen et al. 2009). The network between the primary metabolism and secondary metabolism is very complex and is balanced by their interconversion (Aharoni and Galili 2011).

The survival rate during acclimatization reached $100 \%$, except for the condition of absence of sucrose without a gas permeable membrane

Plants grown in the absence of sucrose and without a membrane (PVC and RP) did not grow under in vitro conditions. Therefore, ex vitro development was severely compromised and no plants survived the acclimatization phase. However, plants subjected to the other treatments showed a survival rate of $100 \%$ when transferred from in vitro to ex vitro conditions. Plants from treatments with sucrose-supplemented medium and PTFE membranes showed greater resistance during the transfer, without the typical stress characteristics of this stage of in vitro growth.

In additon, Seon et al. (2000) observed that in plants from heterotrophic conditions the content of sugars decreased continuously after acclimatization, whereas plants from photoautootrophic conditions had better control of transpiration. Thirty days after transfer, the plants that survived showed uniform development, regardless of their condition during in vitro cultivation.

There are several advantages to reducing sugar in the culture medium, such as preventing the rapid growth of bacteria or fungi in the cultures, reducing costs and increasing plant survival during acclimatization (Kozai and Kubota 2001; Xiao and Kozai 2006). Photoautotrophic propagation improves in vitro, explant growth rates, physiological characteristics, plant photosyntethic competence and water relations, promoting plantlet hardening (Desjardins et al. 1987; Deng and Donnely 1993; Afreen et al. 2002). For $P$. glomerata, the removal of the carbohydrate source from the culture medium did not affect growth when associated with gas permeable PTFE membranes.

The important effect of increasing gas exchange in plant tissue culture vessels on morphogenesis has been studied (Kitaya et al. 2005; Mohamed and Alsadon 2010; Xiao et al. 2011). Our findings indicate that Pfaffia has a high potential for photoautotrophic propagation. The vitroplants in this study showed a vigorous growth pattern supported by increased gas exchange, which promoted the production of seedlings with desirable morphological and physiological characteristics needed for acclimatization. Moreover, 
this is the first report in the literature that describes the influence of the photoautotrophic system on increasing the production of secondary metabolites. The increase in $20 \mathrm{E}$ levels provided by the photoautotrophic system offers new prospects, not only to increase commercial production of $P$. glomerata, but also for basic studies aiming at elucidate the biosynthetic pathway of phytoecdisteroids in plants. In vitro culture systems based on $\mathrm{CO}_{2}$ enrichment may represent a promising alternative for mass propagation of this species and the enhancement of $20 \mathrm{E}$ levels.

Acknowledgments This study was part of the Ph.D. thesis of LI, which was supported by a CAPES fellowship. This work was also supported by the National Council of Research (CNPq) [MCT/CNPq 480675/2009-0; PQ 303201/2010-0 to WCO] and a grant from the Minas Gerais State Research Foundation (FAPEMIG) [CAG-APQ01036-09]. The Microscopy and Microanalysis Center of the Federal University of Viçosa is also acknowledged.

\section{References}

Afreen F, Zobayed SMA, Kozai T (2002) Photoautotrophic culture of Coffea arabusta somatic embryos: photosynthetic ability and growth of different stages of embryos. Ann Bot 90:11-19. doi: 10.1093/aob/mcf150

Aharoni A, Galili G (2011) Metabolic engineering of the plant primary-secondary metabolism interface. Curr Opin Biotech 22:239-245. doi:10.1016/j.copbio.2010.11.004

Aitken-Christie J, Kozai T, Smith MAL (1995) Automation and environmental control in plant tissue culture. Kluwer, Dordrecht

Alves RBN, Bertoni BW, Vieira RF, França SC, Ming LC, Pereira AMS (2010) Influência de diferentes meios de cultura sobre o crescimento de Pfaffia glomerata (Spreng.) Pedersen (Amaranthaceae) para conservação in vitro. Rev Bras Plantas Med 12:510-515. doi:10.1590/S1516-05722010000400016

Badr A, Angers P, Desjardins Y (2011) Metabolic profiling of photoautotrophic and photomixotrophic potato plantlets (Solanum tuberosum) provides new insights into acclimatization. Plant Cell Tiss Organ Cult 107:13-24. doi:10.1007/s11240-0119951-5

Bakrim A, Maria A, Savah F, Lafont R, Takvorian N (2008) Ecdysteroids in spinach (Spinacia oleracea L.): biosynthesis, transport and regulation of levels. Plant Physiol Biochem 46:844-854. doi:10.1016/j.plaphy.2008.06.002

Cha-um S, Chanseetis C, Chitakovid W, Pichakum A, Supaibulwatana K (2011) Promoting root induction and growth of in vitro macadamia (Macadamia tetraphylla L. "Keaau") plantlets using $\mathrm{CO}_{2}$-enriched photoautotrophic conditions. Plant Cell Tiss Organ Cult 106:435-444. doi:10.1007/s11240-011-9940-8

Chen H, Jones AD, Howe GA (2006) Constitutive activation of the jasmonate signaling pathway enhances the production of secondary metabolites in tomato. FEBS Lett 58:2540-2546. doi: 10.1016/j.febslet.2006.03.070

Corrêa C Jr, Cortez DAG, Ming LC, Soares W (2006) Fáfia-O ginseng brasileiro (Pfaffia glomerata (Sprengel) Pedersen): aspectos agronômicos e fitoquímicos. Clichetec, Curitiba

Cruz CD (2006) Programa GENES. Versão Windows, versão 2006.4.1. Editora UFV, Minas Gerais

Deng R, Donnely DJ (1993) In vitro hardening of red raspberry through $\mathrm{CO}_{2}$ enrichment and relative hymidity reduction on sugar-free medium. Can J Plant Sci 73:1105-1113. doi:200.235.143.32
Desjardins Y, Gosselin A, Yelle S (1987) Acclimatization of ex vitro strawberry plantlets in $\mathrm{CO}_{2}$ enriched environments and supplementary lighting. J Am Soc Horticult Sci 112:846-851

Dinan L (2001) Phytoecdysteroids: biological aspects. Phytochemistry 57:325-339. doi:10.1016/S0031-9422(01)00078-4

Dinan L, Harmatha J, Volodin V, Lafont R (2009) Phytoecdysteroids: diversity, biosynthesis and distribution. In: Smaggbe G (ed) Ecdysone: structures and functions. Springer, London, pp 3-10

Donnelly DJ, Tisdall L (1993) Acclimatization strategies for micropropagated plants. In: Ahuja MR (ed) Micropropagation of wood plants. Kluwer, Netherlands, pp 153-166

Donnelly DJ, Vidaver WE, Lee KY (1985) The anatomy of tissue cultured red raspberry prior to and after transfer to soil. Plant Cell Tiss Organ Cult 4:43-50. doi:10.1007/BF00041654

Festucci-Buselli RA, Contim LAS, Barbosa LCA, Stuart JJ, Otoni WC (2008a) Biosynthesis and potential functions of the ecdysteroid 20-hydroxyecdysone-a review. Botany 86:978-987. doi:10.1139/B08-049

Festucci-Buselli RA, Contim LAS, Barbosa LCA, Stuart JJ, Veira RF, Otoni WC (2008b) Level and distribution of 20-hydroxyecdysone during Pfaffia glomerata development. Braz J Plant Physiol 20:53-60

Figueiredo LS, Teixeira SL, Freitas SP, Vieira IJC, Martins ER (2004) Comportamento de acessos de Pfaffia glomerata (Spreng.) Pedersen (Amaranthaceae) nas condições de Campos dos Goytacazes-RJ. Rev Bras Plantas Med 7:67-72

Flores R, Brondani D Jr, Cezarotto V Jr, Giacomelli SR, Nicoloso FT (2010) Micropropagation and ecdysone content of the Brazilian ginsengs Pfaffia glomerata and Pfaffia tuberosa. In Vitro Cell Dev Biol Plant 46:210-217. doi:10.1007/s11627-010-9286-7

Fujiwara K, Kozai T (1995) Physical microenvironment and its effects. In: Atiken-Christie J, Kozai T, Smith MAL (eds) Automation and environmental control in plant tissue culture. Kluwer, Netherlands, pp 319-369

Galzy R, Compan D (1992) Remarks on mixotrophic and autotrophic carbon nutrition of Vitis plantlets cultured in vitro. Plant Cell Tiss Organ Cult 31:239-244. doi:10.1007/BF00036230

Gribaudo I, Restagno M, Novello V (2003) Vented vessels affect growth rate of in vitro Vitis vinifera cv. Nebbiolo. Acta Horticult 616:129-133

Hao J, Guan Q (2012) Synthesis of saikosaponins in adventitious roots of Bupleurum chinense by semi-continuous culture. Plant Cell Tiss Organ Cult 108:159-165. doi:10.1007/s11240-0110012-x

Jausoro V, Llorente BE, Apóstolo NM (2010) Structural differences between hyperhydric and normal in vitro shoots of Handroanthus impetiginosus (Mart. ex DC) Mattos (Bignoniaceae). Plant Cell Tiss Organ Cult 101:183-191. doi:10.1007/s11240-0109675-y

Johansen DA (1940) Plant microtechnique. Mc Graw-Hill, New York

Kitaya Y, Ohmura Y, Kubota C, Kozai T (2005) Manipulation of the culture environment on in vitro air movement and its impact on plantlets photosynthesis. Plant Cell Tiss Organ Cult 83:251-257. doi:10.1007/s11240-005-6839-2

Kozai T (1991) Micropropagation under photoautotrophic conditions. In: Debergh PC, Zimmerman RH (eds) Micropropagation: technology and application. Kluwer, Amsterdam, pp 447-469

Kozai T (2010) Photoautotrophic micropropagation-environmental control for promoting photosynthesis. Propag Ornam Plants 10:188-204

Kozai T, Kubota C (2001) Developing a photoautotrophic micropropagation system for woody plants. J Plant Res 114:525-537. doi:10.1007/PL00014020

Kozai T, Sekimoto K (1988) Effect of the number of air exchanges per hour of the closed vessel and the photosynthetic photon flux on the carbon dioxide concentration inside the vessel and the 
growth of strawberry plantlets in vitro. Environ Control Biol 26:21-29

Lafont R, Dinan L (2003) Practical uses for ecdysteroids in mammals including humans: an update. J Insect Sci 3:7

Lee EK, Jin YW, Park JH, Yoo YM, Hong SM, Amir R, Yan Z, Kwon E, Elfick A, Tomlinson S, Halbritter F, Waibel T, Yun BW, Loake GJ (2010) Cultured cambial meristematic cells as a source of plant natural products. Nat Biotech 28:1213-1217. doi: 10.1038/nbt.1693

Lu Q, Wen X, Lu C, Zhang Q, Kuang T (2003) Photoinibition and photoprotection in senescent leaves of field-grown wheat plants. Plant Physiol Biochem 41:749-754. doi:10.1016/S0981-9428 (03)00098-6

Maldaner J, Nicoloso FT, Santos ES, Flores R, Skrebsky EC (2006) Sacarose e nitrogênio na multiplicação in vitro de Pfaffia glomerata (Spreng.) Pedersen. Ciência Rural 36:1201-1206

Maldaner J, Nicoloso FT, Santos ES, Fagundes CK, Flores R, Jucoski GO, Skrebsky EC (2007) Crescimento de plântulas de Pfaffia glomerata (Spreng.) Pedersen cultivadas in vitro sob dois níveis de nitrogênio e sacarose, durante seis subculturas sucessivas e aclimatização. Ciência Rural 37:133-140

Metlen KL, Aschehoug ET, Callaway RM (2009) Plant behavioural ecology: dynamic plasticity in secondary metabolites. Plant, Cell Environ 32:641-653. doi:10.1111/j.1365-3040.2008.01910.x

Mohamed MA, Alsadon AA (2010) Influence of ventilation and sucrose on growth and leaf anatomy of micropropagated potato plantlets. Sci Horticult 123:295-300. doi:10.1016/j.scienta.2009. 09.014

Mosaleeyanon K, Chan-Um S, Kirmanee C (2004) Enhanced growth and photosynthesis of rain tree (Samanea saman Merr.) plantlets in vitro under a $\mathrm{CO}_{2}$-enriched condition with decreased sucrose concentrations in the medium. Sci Horticult 103:51-63. doi: 10.1016/j.scienta.2004.02.010

Murashige T, Skoog F (1962) A revised medium for rapid growth and bioassays with tobacco tissue cultures. Physiol Plant 15:473-497. doi:10.1111/j.1399-3054.1962.tb08052.x

Neumann KH, Bender L (1987) Photosynthesis in cell and tissue culture systems. In: Green CE, Somers DA, Hackett WP, Biesboer DD (eds) Plant tissue and cell culture. Alan R, Liss, pp 151-165

Nicoloso FT, Erig AC, Martins CF, Russowski D (2001) Micropropagação do ginseng brasileiro [Pfaffia glomerata (Spreng.) Pedersen]. Rev Bras Plantas Med 3:11-18

Nicoloso FT, Erig AC, Russowski D, Martins CF (2003) Efeito de doses e fontes de carboidratos no crescimento de plantas de ginseng brasileiro [Pfaffia glomerata (Spreng.) Pedersen] cultivadas in vitro. Ciência Agrotecnol 27:84-90

O'Brien TP, McCully ME (1981) The study of plant structure principles and selected methods. Termarcarphi, Melbourne

Pospíśilová J, Tichá I, Kadlecek P, Haisel D, Plzáková Š (1999) Acclimatization of micropropagated plants to ex vitro conditions. Biol Plant 42:481-497. doi:10.1023/A:1002688208758

Russowski D, Nicoloso FT (2003) Nitrogênio e fósforo no crescimento de plantas de ginseng brasileiro [Pfaffia glomerata (Spreng.) Pedersen] cultivadas in vitro. Ciência Rural 33:57-63

Santamaria JM, Kerstiens G (1994) The lack of control of water loss in micropropagated plants is not related to poor cuticle development. Physiol Plant 91:191-195. doi:10.1111/j.13993054.1994.tb00418.x
Sarasan V, Kite GC, Sileshi GW, Stevenson PC (2011) Applications of phytochemical and in vitro techniques for reducing overharvesting of medicinal and pesticidal plants and generation income for the rural poor. Plant Cell Rep 30: 1163-1172. doi: 10.1007/s00299-011-1047-5

Savio LEB, Astarita LV, Santarém ER (2012) Secondary metabolism in micropropagated Hypericum perforatum L. grown in nonaerated liquid medium. Plant Cell Tiss Organ Cult 108:465-472. doi:10.1007/s11240-011-0058-9

Seon JH, Cui YY, Kozai T, Paek KY (2000) Influence of in vitro growth conditions on photosynthetic competence and survival rate of Rehmannia glutinosa plantlets during acclimatization period. Plant Cell Tiss Organ Cult 61:135-142. doi:10.1023/ A:1006473223286

Shim SW, Hahn EJ, Paek KY (2003) In vitro and ex vitro growth of grapevine rootstock '5BB'as influenced by number of air exchanges and the presence or absence of sucrose in culture media. Plant Cell Tiss Organ Cult 75:57-62. doi:10.1023/ A: 1024695510994

Skrebsky EC, Nicoloso FT, Ferrão GE (2004) Sacarose e período de cultivo in vitro na aclimatização ex vitro de ginseng brasileiro [Pfaffia glomerata (Spreng.) Pedersen]. Ciência Rural 34: $1471-1477$

Tsay HS, Lee CY, Agrawal DC, Basker S (2006) Influence of ventilation closure, gelling agent and explant type on shoot bud proliferation and hyperhydricity in Scrophularia yoshimurae-a medicinal plant. In Vitro Cell Dev Biol Plant 42:445-449. doi: 10.1079/IVP2006791

Ueda K, Yoshioka S (1976) Cell wall development of Micrasterias americana, especially in isotonic and hypertonic solutions. J Cell Sci 21:617-631

Vieira RF, Silva SR, Alves RBN, Silva DB, Wetzel MMVS, Dias TAB, Udry MC, Martins RC (2002) Estratégias para conservação e manejo de recursos genéticos de plantas medicinais e aromáticas. Resultados da $1^{\text {a }}$ Reunião Técnica. Embrapa Recursos Genéticos e Biotecnologia, Brasília: Ibama, CNPq, Brasil, 184p

Wellburn AR (1994) The spectral determination of chlorophylls $a$ and $b$, as well as total carotenoids, using various solvents with spectrophotometers of different resolution. J Plant Physiol 144:307-313

Xiao Y, Kozai T (2006) In vitro multiplication of statice plantlets using sugar-free media. Sci Horticult 109:71-77. doi:10.1016/ j.scienta.2006.02.029

Xiao Y, Niu G, Kozai T (2011) Development and application of photoautotrophic micropropagation plant system. Plant Cell Tiss Organ Cult 105:149-158. doi:10.1007/s11240-010-9863-9

Zare K, Nazemiyeh H, Movafeghi A, Khosrowshahli M, MotallebiAzar A, Dadpour M, Omidi Y (2010) Bioprocess engineering of Echium italicum L.: induction of shikonin and alkannin derivates by two-liquid-phase suspension cultures. Plant Cell Tiss Organ Cult 100:157-164. doi:10.1007/s11240-009-9631-x

Zhao J, Davis LC, Verpoorte R (2005) Elicitor signal transduction leading to production of plant secondary metabolites. Biotechnol Adv 23:283-333. doi:10.1016/j.biotechadv.2005.01.003

Zobayed SMA (2006) Aeration in plant tissue culture. In: Dutta Gupta S, Ibaraki Y (eds) Plant tissue culture engineering. Springer, Netherlands, pp 313-327 